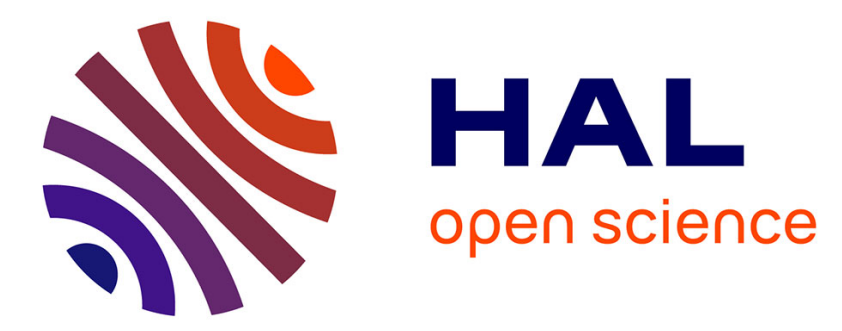

\title{
What matters in Residential Energy Consumption? Evidence from France
}

\author{
Anna Risch, Claire Salmon
}

\section{To cite this version:}

Anna Risch, Claire Salmon. What matters in Residential Energy Consumption? Evidence from France. 2013. hal-01081953

\section{HAL Id: hal-01081953 \\ https://hal.univ-smb.fr/hal-01081953}

Preprint submitted on 12 Nov 2014

HAL is a multi-disciplinary open access archive for the deposit and dissemination of scientific research documents, whether they are published or not. The documents may come from teaching and research institutions in France or abroad, or from public or private research centers.
L'archive ouverte pluridisciplinaire HAL, est destinée au dépôt et à la diffusion de documents scientifiques de niveau recherche, publiés ou non, émanant des établissements d'enseignement et de recherche français ou étrangers, des laboratoires publics ou privés. 


\title{
What matters in Residential Energy Consumption?
}

\author{
Evidence from France
}

\author{
Anna Risch $^{*} \quad$ Claire Salmon ${ }^{\dagger}$
}

September 2013

\begin{abstract}
Given objectives set by countries to realize energy-savings and decrease greenhouse gas emissions, an understanding of the main factors driving household energy consumption is crucial for the formulation of efficient policy measures. Our objective is to identify the main determinants of households energy consumption. The model incorporates a discrete/continuous decision framework, which allows for interactions between decisions on the heating system (the discrete choice) and decisions on the consumption of energy (the continuous choice). We have three main contributions. First, we explore the role of households' socio-economic characteristics vs. technical properties of dwelling in explaining energy consumption. Second, we identify some of the main sources of energy conservation in the housing sector. Third, we estimate price-elasticity and income-elasticity in the French housing sector at a micro-level. Results show that the intensity of energy used per $\mathrm{m}^{2}$ is almost completely determined by the technical properties of the dwelling and by the climate. The role of sociodemographic variables is particularly weak. This means that the challenge to environmental policies is to encourage households to undertake renovations.
\end{abstract}

Keywords: energy consumption, discrete/continuous choice model, heating system JEL classification: Q41, D12, R21

\footnotetext{
* IREGE, Université de Savoie and ADEME

${ }^{\dagger}$ IREGE, Université de Savoie
} 


\section{Introduction:}

There is a growing interest in reducing energy consumption and associated greenhouse gas emissions. Following the 2009 United Nations Climate Change Conference (including the major emerging countries, the United States and Europe), several countries have pledged to reduce their greenhouse gas emissions. The United States committed to decrease its greenhouse gas emissions by $17 \%$ below 2005 levels by the end of this decade and Europe to cut it by $20 \%$ by 2020 compared to 1990 . A great effort is required to reach these objectives. One of the most important energy consumer in these countries is the residential sector, which accounts for around onequarter of the total energy consumption (Odyssee, 2013; IAE, 2013). Therefore, to design adequate energy policies and achieve a low carbon society, an in-depth understanding of residential energy consumption is needed. Indeed, a measure will be efficient only if households are sensitive to it. Consequently, we need to understand households behavior to decrease significantly energy consumption in residential sector. In this study, our objective is to identify the main determinants of households' energy consumption, taking into account five categories of variables, explored in the literature: types of fuel used, energy prices, technical buildings properties, climate areas and households characteristics. Our main contributions are first, to investigate the ability of household socio-demographic characteristics to explain energy consumption per squared meter compared to that of the technical properties of the dwelling and of the climatic specificities of the surrounding area. This means we estimate the contribution of the different categories of variables to explain households' energy consumption. Second, we identify some of the main sources of energy conservation in the housing sector. Third, we propose an estimation of the price-elasticity and income elasticity of energy consumption by squared meter. The objective is to determine what should be the target of environmental policies.

We focus on French households' energy consumption. Several environmental policies have been introduced in France to encourage households to undertake energy-saving investment (as a tax credit or a subsidy). We have to study the determinant of energy consumption to determine if these kinds of policies are appropriate to decrease energy 
consumption. Moreover, literature on French energy consumption is sparse. This is related to the lack of French energy consumption data. To our knowledge, studies using French data focus on electric heating (Cayla et al. 2010) and on the part of income devoted to energy consumption (Cayla et al. 2011). Our objective is to gain greater insight into the determinants of energy consumption in France by taking into account several heating systems, including collective heating. We use 2006 Enquête Logement, a disaggregated, household-level survey data set representative of the French residential sector. It provides large information on households and building characteristics. It also allows calculating the final energy consumption by $\mathrm{kWh} / \mathrm{m}^{2}$ for each household. We estimate energy consumption conditional to the heating system, using a discrete-continuous methodological framework, and we find that households' socio-demographic characteristics play a weak part in explaining the intensity of energy used. Energy consumption is largely determined by dwelling quality and energy prices. In particular, it appears that the replacement of collective heating systems by individual one can help to significantly decrease energy consumption in residential sector. To be efficient, an environmental policy has to encourage households to renovate and adopt energy efficient equipment.

Section 2 reviews the literature on the determinant of energy consumption and section 3 presents the data. Section 4 focuses on the discrete/continuous model, and the results are presented in section 5. We discuss the implications of results and conclude in section 6.

\section{Literature:}

We identify five groups of variables explaining energy consumption in the literature: energy prices, technical buildings properties, climate areas and households characteristics and the role of appliances or of types of fuel used.

\section{Energy prices}

Most literature have focused on the impact of energy prices on energy consumption (Parti and Parti, 1980; Dubin and McFadden, 1984; Baker et al., 1989; Branch, 1993; Bernard et al., 1996; Nesbakken, 1999, 2001; Halvorsen et al., 2001; Labandeira et al., 2006). There is a considerable variation in estimates of energy price elasticities, 
ranging in absolute values from 0.20 to 1.14 for own-price elasticity of electricity, and from 0.04 to 1.6 for own-price elasticity of natural gas. The own-price elasticity of fuel oil has rarely been estimated: the estimate obtained by Newell and Pizer (2008) in the commercial sector is particularly high, reaching 2.95 (see table 1).

Table 1: Estimates of income elasticities and price elasticities for energy consumption in the literature

\begin{tabular}{|c|c|c|}
\hline & $\begin{array}{c}\text { Price } \\
\text { elasticity }\end{array}$ & $\begin{array}{l}\text { Income } \\
\text { elasticity }\end{array}$ \\
\hline \multicolumn{3}{|l|}{ Discrete-continuous choice analysis } \\
\hline $\begin{array}{l}\text { Bernard, J. T., D. Bolduc and D. Bélanger (1996). Quebec residential } \\
\text { consumption for electricity. First step: heating equipment and IV-method. } \\
\text { Short-run results. Own-price elasticity of electricity } \\
\text { Cross-price elasticities of: Oil } \\
\text { Gas }\end{array}$ & $\begin{array}{r}-0.67 \\
0.04 \\
0.08\end{array}$ & 0.14 \\
\hline $\begin{array}{l}\text { Dubin, J. A. and D. L. McFadden (1984). USA. First step: heating and } \\
\text { water equipment. Elasticities of household electricity demand, including } \\
\text { portfolio shift. Own-price elasticity of electricity } \\
\text { Cross-price elasticity of gas }\end{array}$ & $\begin{array}{l}-0.26 \\
0.39\end{array}$ & 0.02 \\
\hline $\begin{array}{l}\text { Halvorsen B. and B.M. Larsen (2001). Norway. Longitudinal approach. } \\
\text { Analysis of flexibility of household electricity consumption over time. } \\
\text { Survey of Consumer Expenditure, 1974-1994. } \\
\text { Short run electricity elasticity } \\
\text { Long run electricity elasticity }\end{array}$ & $\begin{array}{l}-0.43 \\
-0.44\end{array}$ & \\
\hline $\begin{array}{l}\text { Labandeira X., Labeaga J. M., and M. Rodriguez (2006). Spain, household } \\
\text { micro-data. Demand model for a simultaneous analysis of energy goods, } \\
\text { IV-method. Results from whole sample, uncompensated own-price } \\
\text { elasticities of: Electricity } \\
\text { Natural gas } \\
\text { LPG }\end{array}$ & $\begin{array}{l}-0.79 \\
-0.04 \\
-0.36\end{array}$ & \\
\hline $\begin{array}{l}\text { Nesbakken R. (2001). Norwegian micro-data. Simultaneous discrete- } \\
\text { continuous choice model (heating equipment). Short-run results. }\end{array}$ & -0.21 & 0.06 \\
\hline $\begin{array}{l}\text { Nesbakken R. (1999). Norway. Simultaneous discrete-continuous choice } \\
\text { model (heating equipment). Short run results, from pooled data 1993-95. }\end{array}$ & -0.50 & 0.01 \\
\hline $\begin{array}{l}\text { Newell R. G. and W. A. Pizer (2008). US commercial sector. Long-run } \\
\text { results, from a detailed model then aggregated with fuel choice variable. } \\
\text { Own-price elasticities of: Electricity } \\
\text { Natural gas } \\
\text { Fuel oil } \\
\text { District services }\end{array}$ & $\begin{array}{l}-1.14 \\
-1.60 \\
-2.95 \\
-0.88\end{array}$ & \\
\hline $\begin{array}{l}\text { Vaage K. (2000). Norway. Household's energy consumption. First step: } \\
\text { heating equipment. Long-run results, from a reduced model. }\end{array}$ & -1.24 & \\
\hline Conditional Demand Analysis & & \\
\hline $\begin{array}{l}\text { Baker and al. (1989). United Kingdom. Study household gas and } \\
\text { electricity expenditures: Electricity } \\
\text { Gas }\end{array}$ & $\begin{array}{r}-0.758 \\
-0.311\end{array}$ & $\begin{array}{l}0.131 \\
0.115\end{array}$ \\
\hline $\begin{array}{l}\text { Branch (1993). U.S. Study electricity consumption with a GLS estimator. } \\
\text { Electricity }\end{array}$ & -0.20 & 0.23 \\
\hline $\begin{array}{l}\text { Garbacz (1984). Estimation of the U.S. electricity consumption via 2SLS. } \\
\text { Marginal price }\end{array}$ & -0.13 to -0.59 & \\
\hline $\begin{array}{l}\text { Leth-Petersen and Togeby (2001), Denmark, Panel data period 1984-1995. } \\
\text { Oil } \\
\text { District heating }\end{array}$ & $\begin{array}{l}-0.08 \\
-0.02\end{array}$ & \\
\hline $\begin{array}{r}\text { Meier and Rehdanz (2010). UK, household-level panel data. Oil } \\
\text { Gas }\end{array}$ & $\begin{array}{l}-0.4 \text { to }-0.49 \\
-0.34 \text { to }-0.56\end{array}$ & \\
\hline Parti and Parti (1980). Demand for electricity for San Diego County. & -0.58 & 0.15 \\
\hline
\end{tabular}




\section{Technical properties of dwelling:}

Also, a large attention has been paid to the impact of the technical properties of a housing (insulation, year of construction, building materials, design of the building) on energy consumption. Newer buildings tend to consume less energy (Santin et al., 2009; Rehdanz, 2007; Vaage, 2000) and this lead Leth-Petersen and Togeby (2001) to conclude that buildings regulations play a significant role in improving energy efficiency in new buildings in Denmark. Some other results do not converge. If as we can expect, Santin et al. (2009) show that the insulated surfaces has a negative effect on energy consumption, Sardianou (2008) find no evidence of the impact of thermal quality of the building. Also, the latter finds no significant impact of housing type (detached or non detached houses), whereas it is an important explanatory variable for Nesbakken (2001) or Vaage (2000).

\section{Climate areas}

Climate data such as average outside temperatures are generally taken into account in empirical studies and have a significant impact on energy consumption (Nesbakken, 1999; Meier and Rehdanz, 2010; Vaage, 2000).

\section{Income and households' characteristics}

With the exception of income, household characteristics have received less attention in the literature. Income-elasticity is estimated to be very low at less than 0.23 (Branch, 1993) and several studies find an income-elasticity lower than 0.1 (Dubin and McFadden, 1984; Nesbakken, 2001 and 1999). Energy consumption is weakly responsive to an increase of income (see table 1). Moreover, to our knowledge, Cayla et al (2010) and Cayla et al. (2011) are the sole studies using micro-data to explore energy consumption in the French residential sector. They focus on electric heating (Cayla et al. 2010) and on the part of income devoted to energy consumption (Cayla et al. 2011). They underscore the role of household income: households with lowest income are not in a position to make investments in higher performing equipment.

Some other socio-demographic variables are studied in the literature. The age of the reference person and the household size have a positive impact on the energy 
consumption ceteris paribus (Meier and Rehdanz, 2010; Santin et al., 2009). The effect of tenure is indeterminate. Some studies find that owner tend to consume more energy than tenant (Sardianou, 2008; Vaage, 2000), other find an opposite result (Rehdanz; 2007) or no significant effect (Meier and Rehdanz, 2010).

It is noteworthy that very few studies exploit data on actual household behaviour (inside temperature, use of bath or shower, number of hours of presence at home, individual strategies to reduce energy costs...) or preferences regarding comfort. However, Vringer et al. (2007) find no relation between the total household energy requirement and their value patterns or problem perception of climate change.

\section{Appliances or fuel used}

Energy consumption is embedded in a complex system. Indeed, energy provides utility not directly but indirectly through the use of a stock of appliances. Therefore, energy consumption has to be studied conditionally to the stock of appliances. In most papers, only the heating system is taken into account (Bernard et al., 1996; Nesbakken, 1999, 2001; Vaage, 2000). Dubin and McFadden (1984) for example, consider only the space and water heating fuel choice, treating other appliances owned by the household as exogenous. This is not too restrictive given the large weight of heating in households' energy consumption.

Some papers focus in a first step on the heating system and explain this choice by most of the variables explaining energy consumption (as households and buildings characteristics, climate areas) and by variables explaining only the choice of heating system as the availability of fuel and relative utilisation costs (Nesbakken, 1999, 2001; Vaage, 2000; Newell and Pizer, 2008; Braun, 2010). Vaage (2000) shows with Norwegian data that the probability of choosing electricity as only fuel for heating increase with the income, and this fuel for heating system is more often chosen in flats and new buildings. Moreover, households that only have electric heaters use far less energy than households using other heating systems (Nesbakken, 1999).

Our objective is to determine the weight of each category of variable to explain energy consumption. The main determinant of energy consumption in the literature are summarize in the following chart. 
Chart 1: Main determinants of heating system choice and energy consumption found in literature

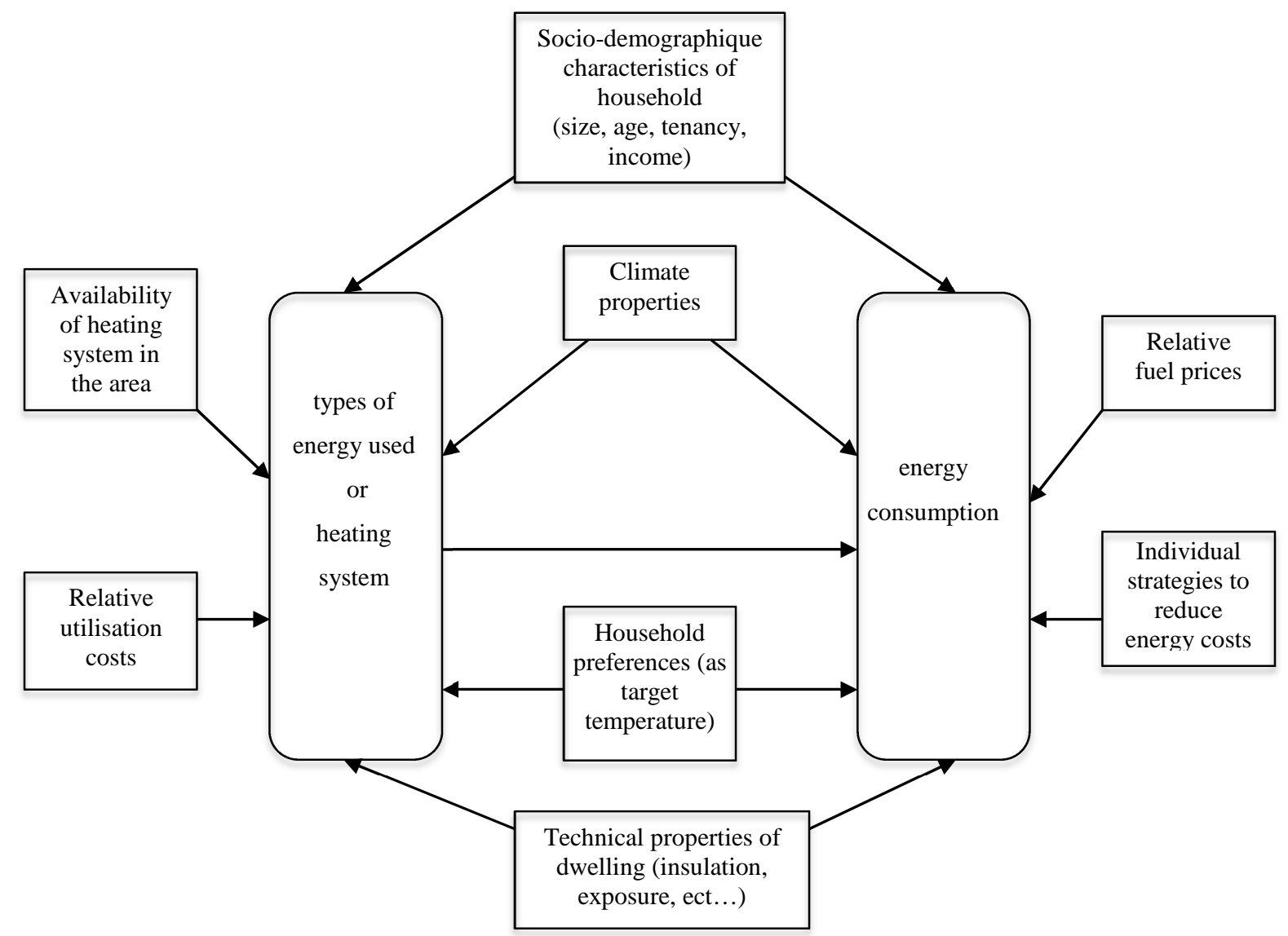

\section{Data:}

Our objective is to understand the main driver of energy consumption. We explore both the main determinants of energy consumption per $\mathrm{m}^{2}$ and the main contribution of each variables category presented in Chart 1 to explain energy consumption per $\mathrm{m}^{2}$. We use the 2006 Enquête Logement (INSEE), a disaggregated household-level survey data set, representative of the French residential sector. This survey provides information on 36955 households and gives large information on the housing, heating system, household characteristics and geographical information. Moreover few household-level data on the French energy consumption are available. However, Enquête Logement survey allows calculating the energy consumption by $\mathrm{kWh} / \mathrm{m}^{2}$. 
Variables are presented in the following table. We first present the main features of the French housing sector, before focus on energy consumption.

Table 2 - Description of variables

\begin{tabular}{|c|c|c|}
\hline Variables & $\begin{array}{c}\text { Name } \\
\text { of } \\
\text { Vector }\end{array}$ & Description \\
\hline Energy consumption (by $\mathrm{m}^{2}$ ) & & $\begin{array}{l}\text { It is the explained variable. Final energy consumption in } \\
\mathrm{kWh} / \mathrm{m}^{2} \text { is defined as the sum of all energy consumption for all } \\
\text { types of fuels used for residential purposes in a dwelling (use } \\
\text { of appliances, heating, cooling, cooking and lighting). }\end{array}$ \\
\hline $\begin{array}{l}\text { 1. Technical properties of } \\
\text { dwelling }\end{array}$ & DW & \\
\hline Individual house type & & $\begin{array}{l}\text { Dummies: attached houses, semi detached houses, detached } \\
\text { houses }\end{array}$ \\
\hline $\begin{array}{l}\text { Collective dwelling } \\
\text { characteristics }\end{array}$ & & Number of dwellings in block of flats; floor \\
\hline Size & & Dwelling size in $\mathrm{m}^{2}$ \\
\hline Specificities & & $\begin{array}{l}\text { Dummies: } \operatorname{roof}<3 \mathrm{~m} \text {, professional room in the dwelling; } \\
\text { veranda, damp, cellar not converted, attic }\end{array}$ \\
\hline Construction date (vintage) & & $\begin{array}{l}\text { Dummies: Before 1948; between } 1949 \text { and 1974; between } \\
1975 \text { and 1989; between } 1990 \text { and } 2005\end{array}$ \\
\hline Insulation characteristics & & $\begin{array}{l}\text { Dummies: double glazing, recent roof insulation, sufficient } \\
\text { roof insulation, insufficient roof insulation, nonexistent roof } \\
\text { insulation }\end{array}$ \\
\hline $\begin{array}{l}\text { Exposure (according to } \\
\text { households) }\end{array}$ & & Dummies: poor exposure, medium exposure, good exposure \\
\hline Location & & Dummies: downtown, suburb, rural town. \\
\hline 2. Climate areas & $\mathbf{C L}$ & $\begin{array}{l}\text { In France, regions are divided into } 7 \text { different climate areas } \\
\text { (see Map in appendix). } \\
\text { Dummies: mountain climate, semi continental climate, cooler } \\
\text { oceanic climate, mixed oceanic climate, oceanic climate, mild } \\
\text { oceanic climate, mediterranean climate }\end{array}$ \\
\hline 3. Heating system & HS & $\begin{array}{l}\text { Dummies: collective heating system with gas or fuel, } \\
\text { individual system with electricity, individual system with gas, } \\
\text { individual system with fuel }\end{array}$ \\
\hline 4. Price of energy & $\mathbf{P}$ & $\begin{array}{l}\text { Average energy price: weighted average of different fuel } \\
\text { prices; weights depending on the specific mix of fuels used by } \\
\text { each household. }\end{array}$ \\
\hline $\begin{array}{l}\text { 5. Household socio- } \\
\text { demographic variables }\end{array}$ & SDH & \\
\hline $\begin{array}{l}\text { Demographic } \\
\text { characteristics }\end{array}$ & & $\begin{array}{l}\mathrm{Nb} \text { of persons in the dwelling, age of household member } \\
\text { answering the questions in the survey }\end{array}$ \\
\hline Occupancy statute & & Dummies: own, renter, social-rent, private rent, free housed \\
\hline $\begin{array}{l}\text { Educational level of } \\
\text { household member } \\
\text { answering the questionnaire }\end{array}$ & & $\begin{array}{l}\text { Dummies: without certificate, less than baccalaureate, } \\
\text { baccalaureate, more than baccalaureate. }\end{array}$ \\
\hline Income & & Monthly income per consumption unit \\
\hline
\end{tabular}

\subsection{Main features of the French housing sector}


The residential park is split into two broad categories (houses and flats). The following figures present the main characteristics of these two different residential categories.

Graph 1 - French dwelling characteristics (full sample)
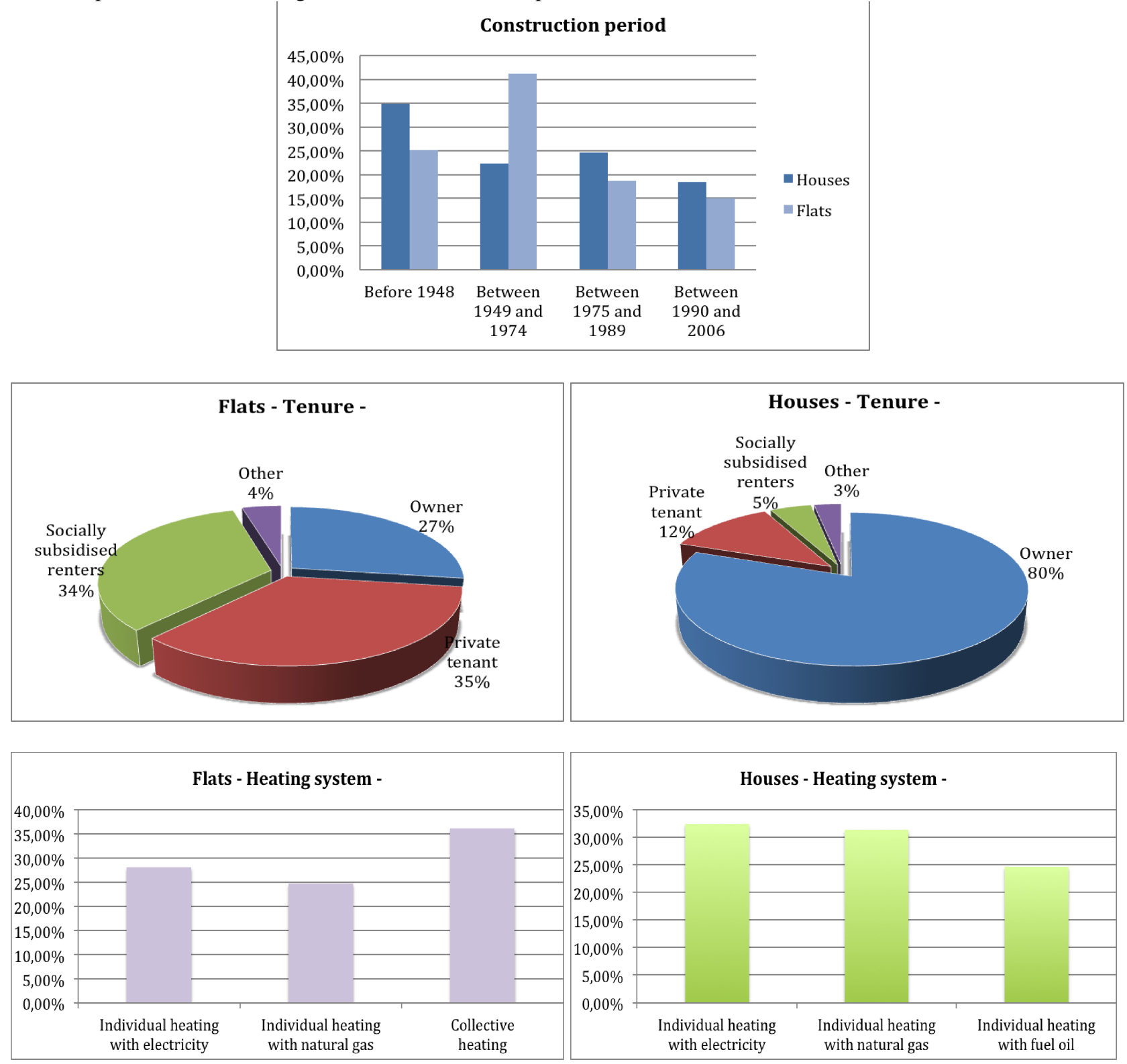

Source: Enquête logement 2006 INSEE - Results for the France

According to the data, $56 \%$ of all dwellings are houses. Residential buildings in France are quite old despite the "building boom" that followed WWII, with nearly $30 \%$ built before 1948 . Flats tend to be of more recent constructions, with $60 \%$ built in the forty-year period between 1949 and 1989. In terms of ownership, 80\% of 
houses are owner-occupied compared to only $27 \%$ of flats. $17 \%$ of dwellings are subsidized housing, these dwellings are allocated according to household income levels and socio-demographic characteristics. Unsurprisingly, houses are significantly larger than flats $\left(111 \mathrm{~m}^{2}\right.$ versus $\left.65 \mathrm{~m}^{2}\right)$.

Globally, nearly $90 \%$ of French dwellings are heated with one of the three main fuels: electricity (31\%), natural gas (38\%), and fuel oil (20\%). However, the fuel used differs according to the dwelling type. For houses, 35\% of households use an electric heater, $31 \%$ a natural gas heater, and $25 \%$ an oil heater. For collective residential buildings, $47 \%$ use a natural gas heater, $30 \%$ an electric heater and $13 \%$ an oil heater. A particularity in France is the existence of collective heating, several households living in the same block of flats and sharing the same heating system. However, a majority (53\%) of households living in flats use an individual heating system. For the remainder, in the absence of individual meters, the relation between their own energy consumption and their actual energy expenditures may be particularly unclear (Levinson and Niemann, 2004).

As the characteristics of houses and flats are significantly different, we study the energy consumption separately for these two types of housing. Moreover, as nearly 90\% of French households use oil, electricity or natural gas, we focus our analysis on these three fuel types (see Table 1). Households, which mainly use wood, coal or a district service for heating, have therefore been excluded. Crossing the category of dwelling with the type of heating system, we obtained 6 different segments (Table 3).

Table 3 - Presentation of the 6 different segments

\begin{tabular}{ll}
\hline Housing category & Segment by type of heating system \\
\hline \multirow{3}{*}{ Flats } & 1. Individual electric heat \\
& 2. Individual natural gas heat \\
& 3. Collective natural gas heat (natural gas or fuel oil) \\
\hline \multirow{3}{*}{ Houses } & 4. Electric heat \\
& 5. Natural gas heat \\
& 6. Fuel oil heat \\
\hline
\end{tabular}

\subsection{Energy consumption}

To conduct this study we need to know household energy consumption by $\mathrm{kWh} / \mathrm{m}^{2}$. We can calculate it on the basis of energy expenditures provided by the Enquête 
Logement. This survey gives information on the total expenditure of each household in each fuel (regrouping expenditures for heating, cooling, lighting and other uses of appliances) over the preceding 12 months. Combining this information with the energy prices by $\mathrm{kW} / \mathrm{h}$, we are able to compute household energy consumption. Prices of natural gas, electricity, oil, wood, district service and coal come from the external source: Ministère de l'économie, des finances et de l'industrie. There is no regional difference in energy prices in France. However the prices of electricity and natural gas depend on the use of the fuel (heating, cooking, warm water) and the size of the housing. We take into account these characteristics to determine the unit price by $\mathrm{kW} / \mathrm{h}$ of each fuel and for each household ${ }^{1}$ and then calculate their total energy consumption. This step of the work was particularly tricky and led us to eliminate a significant part of the sample, particularly households using collective heating systems. About $44 \%$ of households using this type of heating system were unable to state their actual energy expenditures in the survey because their energy bill is combined with other shared charges (expenditures for the lift, cleaning of common space, gardening, etc...) that are paid all together. This is an interesting observation per se as we can thereby deduce that about $7 \%$ of French households cannot properly react to any kind of price-signal because they do not perceive the real cost of their energy use. Our final sample is composed of 19849 dwellings. Households using a collective heating still represent a significant part of our sample: $41 \%$ of flats are equipped of collective heating. Moreover, weights have been applied to maintain the sample representative. Proportion of variables as flats and houses, tenure, and construction period are still respected.

Table 4 presents the average energy consumption by type of heating system (in $\mathrm{kWh} / \mathrm{m}^{2}$ ). We observe that final energy consumption is significantly higher for houses than for flats: $201 \mathrm{~kW} / \mathrm{h} / \mathrm{m}^{2}$ per year for houses versus $178 \mathrm{~kW} / \mathrm{h} / \mathrm{m}^{2}$ for flats. These results are in the range of what is commonly compute in the French residential sector (ANAH, 2008).

It is noteworthy that households equipped with an electric heater consume significantly less energy compared to those heating with other fuels. The difference in

\footnotetext{
${ }^{1}$ Price of $\mathrm{kW} / \mathrm{h}$ is $0.0645 €$ for oil, $0.0594 €$ on average for natural gas, and $0.1005 €$ on average for electricity.
} 
energy consumption per $\mathrm{m}^{2}$ between users of electric and oil heat is particularly striking for households living in houses.

Interestingly, in flats, households using a collective heating system register significantly higher energy consumption on average than those using an individual heating system. This can be explained by both the higher level of energy used when the energy is a public good (the incentive to reduce consumption is weak) and the difference of energy type used (mainly gas and fuel oil). Concerning the first explanation, Levinson and Niemann (2004) showed on American data that energy consumption is generally higher when tenants do not face the marginal cost of their own energy use. That is the case when collective heating is not associated with individual metering or when a household cannot modulate the temperature of its own flat, which is a common situation in France in flats heated by a collective heating system. That is also the case when energy costs are included in the monthly rent. In these situations, tenants have little incentive to use energy efficiently. Maruejols and Young (2011) show that split incentives result from bill-paying arrangements. Households who do not pay directly for their heat but instead have these costs included in their rent or condo fees opt for a higher thermal comfort.

Table 4 - Final energy consumption by heating system for individual houses and flats:

\begin{tabular}{|c|c|c|c|c|c|c|}
\hline & \multicolumn{3}{|c|}{ Houses } & \multicolumn{3}{|c|}{ Flats } \\
\hline & \multicolumn{2}{|c|}{$\begin{array}{c}\text { Final energy } \\
\text { consumption }\left(\mathrm{kWh} / \mathrm{m}^{2}\right)\end{array}$} & \multirow{2}{*}{$\begin{array}{l}\text { Weight of } \\
\text { this segment } \\
\text { in the park }\end{array}$} & \multicolumn{2}{|c|}{$\begin{array}{c}\text { Final energy } \\
\text { consumption }\left(\mathrm{kWh} / \mathrm{m}^{2}\right)\end{array}$} & \multirow{2}{*}{$\begin{array}{l}\text { Weight of } \\
\text { this segment } \\
\text { in the park }\end{array}$} \\
\hline & Mean & SD & & Mean & SD & \\
\hline Individual heating: & & & & & & \\
\hline Electricity & 158.93 & 74.39 & $21.57 \%$ & 146.33 & 77.00 & $14.64 \%$ \\
\hline Natural gas & 216.52 & 84.37 & $18.51 \%$ & 194.64 & 89.47 & $10.82 \%$ \\
\hline Fuel & 239.33 & 89.89 & $16.49 \%$ & - & - & - \\
\hline Collective heating & - & - & - & 194.59 & 83.22 & $17.87 \%$ \\
\hline Total & 201.24 & 89.30 & $56.67 \%$ & 178.30 & 85.90 & $43.33 \%$ \\
\hline Number of observations & \multicolumn{3}{|c|}{11476} & \multicolumn{3}{|c|}{8373} \\
\hline
\end{tabular}

Source: Enquête logement 2006 INSEE

NB: Weights have been applied to maintain the sample representative

\section{Method}

According to the previous section, the energy consumption for residential needs (heating, cooking, cooling, lighting, use of appliances) ranges from $146 \mathrm{kWh} / \mathrm{m}^{2}$ to $239 \mathrm{kWh} / \mathrm{m}^{2}$ according to dwelling type and heating fuel type. To better understand this variance, we examined the main determinants of energy consumption per $\mathrm{m}^{2}$ and the main contribution of each variable category to explain energy consumption per 
$\mathrm{m}^{2}$. We estimate energy consumption separately for flats and houses, given the different characteristics between these two kinds of dwelling. 


\subsection{Methodology issues}

Techniques used to model residential energy consumption can be grouped broadly into two main categories: "top-down" and "bottom-up" models. The top-down approach considers the residential sector as a whole and does not consider energy consumption broken down into individual uses. The bottom-up approach encompasses all models which use input data. A precise review of these techniques can be found in Swan and Ugursal (2009) and Zagamé (2008). As we want to estimate energy consumption we focus on the latest approach. The explained variable is the final energy consumption in $\mathrm{kWh} / \mathrm{m}^{2}$, defined as the sum of all energy consumption for all types of fuels used for residential purposes in a dwelling (use of appliances, heating, cooling, cooking and lighting). We observe only one year therefore we cannot control for unobserved heterogeneity. Moreover, we face to two potential problems of endogeneity. The first one is related to the stock of appliances or the heating system and the second one is related to energy prices.

Households do not consume energy for itself but energy provides utility indirectly through the use of heating system, lighting or appliances. The process of energy consumption could be described as a two-steps process. First, households choose their heating system or their stock of appliances. Second, they decide how energy to consume given the available technology (relating to the inside temperature for example). This lead to a potential endogenous problem of the stock of appliances and we have to take into account it to obtain unbiased results. Two general methodological frameworks are employed to estimate residential energy consumption: conditional demand analysis and discrete-continuous choice analysis. The first methodology estimates energy consumption conditional on a given stock of appliances (Baker et al., 1989; Branch, 1993; Larsen and Nesbakken, 2004). This approach was proposed by Parti and Parti (1980), who disaggregated the total household consumption for electricity into a set of component demand functions for electricity usage in 16 appliance categories. It was then used in several studies (LethPetersen and Togeby, 2001; Rehdanz, 2007; Meier and Rehdanz, 2010) They focus only on the continuous energy consumption, without taking into account possible changes in equipment stock. Moreover, this approach requires a dataset with information on the ownership of a variety of appliances (Swan and Ugursal, 2009). 
The second modelling methodology uses discrete and continuous choice analysis. An assumption of this framework is that, due to this dependency on appliance use, elasticities should not be estimated exclusively on the basis of one energy equation, but also on the choice of fuels for heating, cooling, and the stock of other appliances. It is common in the literature that the demand for appliances using energy and the demand for energy itself caused by the use of these appliances are assessed in different steps. In a first step the probability to use a specific heating system for example is estimated, and in a second step the energy consumption is analysed, introducing as explanatory variable the estimated probability of using the specific heating system. The joint discrete-continuous decision framework allows taking into account interrelation between the choice of appliances and the choice of intensity of energy used. This two-stage model is largely used in the literature to correct endogeneity of discrete variable (Heckman and Robb, 1985). Dubin and McFadden (1984) are the first to apply this approach to estimation of residential energy consumption. They use U.S. household data to simultaneously model the choice of appliances and the energy consumption. This allows avoiding the potential endogeneity bias resulting from unobserved factors that influence both appliance choice and its intensity of use. This approach was then used by many authors (Baker and Blundell, 1991; Bernard et al., 1996; Nesbakken, 1999; Vaage, 2000; Nesbakken, 2001; Newell and Pizer, 2008). We focus in this paper on the second approach.

Moreover, one of our objectives is to estimate price elasticity. We introduced as explanatory variable in the second step the average energy price (calculated as the weighted average of different fuel prices, weights depending on the specific mix of fuels used by each household). To tackle this potential problem, we use instrumental variable to estimate the energy consumption choice.

\subsection{Model}

We focus on a discrete-continuous model, based on the common hypothesis that there is a relationship between a heating technology and the intensity of use of the technology. In the first stage of our model, decisions regarding space-heating systems are modelled with a multinomial probit. This is the "heating system choice". Due to 
data limitations in the 2006 Enquête Logement, we can only examine heating system choices and we have to ignore appliances and energy consumption due to cooking and light. However, given the considerable weight of heating expenditures in French households' total residential energy expenditures, which is assessed at about $70 \%$ of total energy consumption by INSEE, one may consider that this restriction does not prevent to set insights. Moreover, it is noteworthy that in most papers, the choice of heating system is estimated in the first step and the total energy consumption in the second step (Bernard et al., 1996; Nesbakken, 1999, 2001; Vaage, 2000). Therefore, we estimate the probability that the household choose one of the three mutually exclusive type of heating system: (i) individual system with electricity, (ii) individual system with gas (iii) collective heating system with gas or fuel, in the flat sector. In the house sector, all houses have an individual heating system, households have to choose between three types of fuel for their main heating system: (i) electricity, (ii) natural gas, (iii) oil. As we saw previously, the choice of heating system (HS) is commonly explained by the same variables that explain energy consumption, this means the technical properties of the dwelling (DW), climate area (CL), sociodemographics characteristics (SDH). Moreover, some variables are found in the literature to explain exclusively the discrete choice, as the availability of fuel in the area (Nesbakken, 1999, 2001; Vaage, 2000; Newell and Pizer, 2008; Braun, 2010). Therefore, we include as explanatory variables the dwelling localization (downtown, suburbs, rural area) this allows for example taking into account the fact that city gas is not available in rural area. We also add a dummy equal to one if the flat or the house is a co-ownership. In this case, the household is not the only one to choose the heating system. These variables are grouped in the vector $\mathrm{Z}$.

$$
H S_{i, k}=\alpha_{0}+\alpha_{1} \mathbf{D W}_{i, k}+\alpha_{2} \mathbf{C L}_{i, k}+\alpha_{3} \mathbf{S D H}_{i, k}+\alpha_{4} \mathbf{Z}_{i, k}+\mu_{i, k}
$$

Conditional on this previous choice, a household then decides how much energy to consume. Therefore, in the second stage, energy consumption (the logarithm of the energy consumption in $\mathrm{kWh} / \mathrm{m}^{2}$ ) conditional on the chosen heating system then is estimated. This is the "energy consumption choice". Estimate jointly the both choices allow capturing the potential correlation between unobservable variables in the discrete and the continuous stages. We estimate it using double least squares model, 
which allows correcting endogeneity issue of energy prices, and we use as instruments previous energy prices. The validity of these instruments is presented in appendix table A.4. Also, a bootstrap correction is applied in the second step to eliminate a potential estimation bias due to the methodology in two steps (Murphy and Topel, 1985). Moreover, we introduced multiplicative variables to correct collinearity problems.

We want to compare the ability of a household's socio-demographic characteristics (SDH) and the energy price $(\mathbf{P})$ to explain energy consumption per $\mathrm{m}^{2}$ with those of the technical properties of the dwelling (DW), heating system (HS), and climatic specificities of the area $(\mathbf{C L})$. First, we estimate a complete model, including all the previously described variables. This complete model estimates the logarithm of energy consumption per $\mathrm{m}^{2}$ in dwelling $i$ belonging to housing category $k$ (flat or house). We introduced the predicted heating system ( $\hat{\mathbf{H} S}$ ).

(i) Complete model:

$$
\ln \left(C_{i, k}\right)=\beta_{o}+\beta_{1} \mathbf{D W}_{i, k}+\beta_{2} \mathbf{C L}_{i, k}+\beta_{3} \hat{\mathbf{H}} \mathbf{S}_{i, k}+\beta_{4} \mathbf{P}_{i, k}+\beta_{5} \mathbf{S D H}_{i, k}+\varepsilon_{i, k}
$$

Second, we test three different nested models to assess how the five categories of variables predict the variance in energy consumption. These nested models are estimated to compare the prediction power of the five different categories of variables (F-Test of a set of coefficient) and the goodness of fit of the reduced model (Adjusted $\mathrm{R}$ squared). The technological model explains the energy consumption by characteristics of building (DW), predicted heating system ( $\hat{\mathbf{H S}}$ ) and climate dummies $(\mathbf{C L})$

(ii) Technological model: $\ln \left(C_{i, k}\right)=\beta_{o}+\beta_{1} \mathbf{D} \mathbf{W}_{i, k}+\beta_{2} \mathbf{C L}_{i, k}+\beta_{3} \hat{\mathbf{H}} \mathbf{S}_{i, k}+\varepsilon_{i, k}$

The eco-technological model is the technological model with the average price $(\mathbf{P})$.

(iii) Eco-technological model:

$\ln \left(C_{i, k}\right)=\beta_{o}+\beta_{1} \mathbf{D} \mathbf{W}_{i, k}+\beta_{2} \mathbf{C L}_{i, k}+\beta_{3} \hat{\mathbf{H}} \mathbf{S}_{i, k}+\beta_{4} \mathbf{P}_{i, k}+\varepsilon_{i, k}$

The socio-demographic model assesses the energy consumption by the household characteristics only (SDH).

(iv) Socio-demographic model: $\ln \left(C_{i, k}\right)=\beta_{o}+\beta_{5} \mathbf{S D H}_{i, k}+\varepsilon_{i, k}$ 


\section{Results}

\subsection{Households characteristics vs. housings technical properties}

Results of the first step are available in appendix (table A.2 and A.3). Building characteristics are somewhat different according to the type of heating system. Briefly, our estimates show that electric heat is mainly chosen by dwellings built after 1975 that are equipped with double glazing; these dwelling are relatively small, mainly located in rural areas and often occupied by tenants rather than their owners. Natural gas heating generally is found in town in rather large, semi-detached houses built between 1949 and 1975 that rarely are equipped with double-glazing and are owner-occupied. Fuel oil heating mainly is found in large detached houses in rural areas that were built before 1974, rarely are equipped with double-glazing, and are occupied by their owner.

Then we estimate the energy consumption choice. We evaluate the explanatory power of the different models presented above and realize tests of a set of coefficients to determine the contribution of each category of variables (households' sociodemographic characteristics, technical properties of housing, energy price, climate area and heating system) to explain energy consumption. Results are very similar for flats and houses. It appears that energy consumption is almost completely determined by technology and climate. Table 5 shows that about $35 \%$ of variance is explained by the complete model. Technical properties of the dwelling, the type of heating system and the climate characteristics of its location (model ii) explained 19\% of variance for houses and $17 \%$ for flats. Substantially higher $\mathrm{R}^{2}$ are obtained by adding the average energy price (model iii) in order to explain the level of energy consumption per $\mathrm{m}^{2}$. It is striking to observe how the socio-demographic model (iv) registers a low $\mathrm{R}^{2}$, emphasizing that the influence of socio-economic factors on energy consumption is weak compared to that of building features and climate. Income and household sociodemographic characteristics only play a weak role in explaining the variance (about $2 \%$ in houses and $4.5 \%$ in flats). In the short run, energy consumption per $\mathrm{m}^{2}$ is only slightly determined little by the household itself. Santin et al. (2009) obtained a similar result on Dutch housing, with only $5 \%$ of variance of energy consumption explained by socio-demographic variables and by household behaviour. They include similar variables that we considered in our model (income, household size, age of 
respondent, tenure) excluded for variables on educational level, but with additional information on temperature in the housing. This result illustrates that, without major investments in building characteristics, households cannot modulate their energy consumption.

Table 5: Comparison of goodness of fit of different models. Variable to explain: consumption by $\mathrm{m}^{2}$ (in ln) in flats. F-test and Adjusted R-squared.

\begin{tabular}{|c|c|c|c|c|}
\hline Variables included & $\begin{array}{l}\text { Complete } \\
\text { model (i) }\end{array}$ & $\begin{array}{l}\text { Technological } \\
\text { model (ii) }\end{array}$ & $\begin{array}{c}\text { Economic } \\
\text { and } \\
\text { technological } \\
\text { model (iii) }\end{array}$ & $\begin{array}{c}\text { Socio- } \\
\text { demographic } \\
\text { model (vi) }\end{array}$ \\
\hline \multicolumn{5}{|l|}{ Results for houses } \\
\hline $\begin{array}{l}\text { Group 1: technical properties of dwelling } \\
\text { DW }\end{array}$ & $\mathrm{F}: 90.42 * * *$ & $\mathrm{~F}: 66.38^{* * *}$ & F: $79.65^{* * *}$ & - \\
\hline Group 2: climate dummies $\mathbf{C L}$ & $\mathrm{F}: 59.35^{* * *}$ & F: $53.98 * * *$ & F: $59.22 * * *$ & - \\
\hline Group 3: heating system $\mathbf{H S}$ & $\mathrm{F}: 13.53 * * *$ & $\mathrm{~F}: 47.61 * * *$ & F: $28.94 * * *$ & - \\
\hline Group 4: price of energy $\mathbf{P}$ & $\mathrm{F}: 413.01^{* * *}$ & - & $\mathrm{F}: 398.56^{* * *}$ & - \\
\hline Group 5: socio-demographic variables & F: $11.53^{* * *}$ & & - & $\mathrm{F}: 27.74 * * *$ \\
\hline SDH & & - & & \\
\hline Adj R-squared & 0.3506 & 0.1965 & 0.3231 & 0.0272 \\
\hline observations & 11476 & 11476 & 11476 & 11476 \\
\hline \multicolumn{5}{|l|}{ Results for flats } \\
\hline $\begin{array}{l}\text { Group 1: technical properties of dwelling } \\
\text { DW }\end{array}$ & $38.67 * * *$ & $68.90 * * *$ & $83.38 * * *$ & - \\
\hline Group 2: climate dummies $\mathbf{C L}$ & $40.10^{* * *}$ & $48.71 * * *$ & $54.89 * * *$ & - \\
\hline Group 3: heating system $\mathbf{H S}$ & $3.29 * *$ & $16.77 * * *$ & $0.19^{\mathrm{ns}}$ & - \\
\hline Group 4: price of energy $\mathbf{P}$ & $412.51 * * *$ & - & $629.01 * * *$ & - \\
\hline Group 5: socio-demographic variables & $47.32 * * *$ & & & $40.42 * * *$ \\
\hline SDH & & - & - & \\
\hline Adj R-squared & 0.3440 & 0.1696 & 0.2978 & 0.0450 \\
\hline Observations & 8373 & 8373 & 8373 & 8373 \\
\hline
\end{tabular}

Note: the complete list of each group of variables is shown in Table 2.

It appears that among the technical properties, the size of the dwelling has a negative impact on energy consumption per $\mathrm{m}^{2}$ (see table 6 below and table A.5 in appendix). Moreover, flats with a better exposure and the more recent construction (built after 1975) have lower energy consumption. In contrast, in houses an unconverted cellar or attic, a veranda or a detached house rather than an attached one tend to increase energy consumption.

Concerning insulation characteristics, double-glazing reduces energy consumption on average in flats, but the effect is less pronounced in the more recently constructed segment. However, the impact of double-glazing is no significant for houses ceteris paribus, except for houses built between 1975 and 1989 (relative to those built before 1948). This surprising result may be due to the "rebound effect". Such an effect appears when investment in a new technology such as double-glazing could entail a 
change in household behaviour (increase of temperature target, for instance) which at least partially offsets the beneficial effects of the technology. In a large survey, Greening et al. (2000) found that a $100 \%$ increase in energy efficiency led to an estimated rebound of 0 to $50 \%$ for residential end uses. In houses, the quality of roof insulation is more efficient to reduce energy consumption than double-glazing.

Also, heating system plays an important role. The energy consumption per $\mathrm{m}^{2}$ is lower in a dwelling heated by electricity than in a dwelling heated by fuel oil, ceteris paribus. There is also a significant difference in consumption per $\mathrm{m}^{2}$ between a dwelling heated by natural gas and one heated by electricity but only in flats. Moreover in the flats sector, there is a strong effect of collective heating on energy consumption. Buildings equipped with a central heater (either natural gas or oil) have significantly higher consumption than those equipped with an individual heater (either natural gas or electricity) ceteris paribus. This is in the line of the result of Santin et al. (2009) who show that in dwelling where heating is included in the rent, more energy is used.

Climate dummies conformed to expectation. The quantity of energy consumed is significantly lower in the areas with a warmer climate: oceanic and mediterranean compared to mountain areas. In contrast, energy consumption is the highest in the semi-continental areas. This confirms the result of Nesbakken (1999) and Meier and Rehdanz (2010).

Price-elasticity in absolute value is equal to 0.46 in houses and 0.86 in flats. With cross-section data, this means that households facing higher average energy prices consume less energy than others. Moreover, the higher price-elasticity in flats means that households living in this kind of dwellings are more responsive to the price of energy. These results are in the range of estimates reported in Table 1. In the literature, there is a considerable variation in estimates of energy price elasticities, ranging in absolute value from 0.04 to 1.6 for the residential sector. 
Table 6: Estimates of household energy consumption per $\mathrm{m}^{2}$ in a year: Individual dwellings

Double least-squared. Explained variable: household energy consumption per $\mathbf{m}^{2}$ a year (in



Note: *** Significant at 1 per cent. ** Significant at 5 per cent. * Significant at 10 per cent. 
Income-elasticity is quite low (0.02) in houses and no significant in flats, which is similar to the average estimates obtained in other studies using household micro-data (see Table 1). In most studies, income-elasticity is estimated to be less than 0.15 . Energy consumption is a normal good, but remains weakly responsive to an increase of income per consumption unit.

Among other socio-demographic characteristics, the age of the head of household and the number of persons living in the dwelling increase the intensity of energy used per $\mathrm{m}^{2}$. Households in which there are people who stay at home consume more energy per $\mathrm{m}^{2}$ than households whose members are employed and work outside the home (this effect is captured by the presence of professional rooms in houses and the type of employment in flats: unemployed or homemakers). Education level is only significant for flats where more educated people consume less energy than less educated ones. Finally, tenants consume more energy that homeowners. Owners have a significantly higher energy consumption compared to tenants occupying private and subsidized housing.

\subsection{Policy implication}

The main policy implication of these results is that France only can reach its objective to reduce energy consumption and associated $\mathrm{CO}^{2}$ emissions by adopting as a very ambitious policy of building renovation or introducing supplementary taxes on energy prices.

As we saw, households' characteristics play a weak part in energy consumption in explaining energy consumption. The number of household members, their income per consumption unit, their education, presence at home, tenancy status and the age of the head of the household are broadly significant, but these variables are unable to explain more than $4.5 \%$ of variance in the intensity of energy used. This means that in the short run, the possibility for a given household in a given dwelling to reduce its energy consumption is extremely weak in the absence of investment in the quality of the lodging. Almost all of the explained variance is attributed to the quality of the dwelling (insulation, double-glazing, exposure, quality of the roof, etc...), the type of 
heating technology, and climate dummies. Given the low turnover rate of housing stock, the main challenge is to encourage households to renovate their dwellings.

Results allow identifying some of the main sources of energy conservation in the French housing sector. Collective heating system is not energy efficient and the installation of individual metering or the replacement of collective systems by individual heating systems could be helpful to decrease energy consumption in collective housing blocks (reference récente à intégrer sur le sujet). Moreover, roof insulation renovations are more efficient to save energy than installation of doubleglazing in houses. Environmental policies should be targeting these kinds of renovations to have a significant effect on energy consumption.

Moreover, in the short run, households are responsive to an increase of their average energy price. This means that France could significantly decrease energy consumption through taxes on energy prices. (reference à intégrer : votre papier avec Dorothée ???).The problem is such a measure affects primarily the poorest people and it raises the issue of energy poverty, but they could be redistributed to fund other environmental policies, as subsidies.

\section{Conclusion}

The residential energy consumption of French households, conditional on their heating system, has been estimated in this study using a micro data-set. Households face a two-stage decision process when determining their energy consumption. They choose which energy to use for their heating system. Conditional on this first step, households then determine how much energy to use in a second step. We estimated energy consumption for two different types of dwellings: houses and flats. We compared the prediction power of four different models for each category of housing: (i) complete model, (ii) technological model (consumption explained by characteristics of building, heating system and climate dummies), (iii) ecotechnological model (technological model with average level of energy price), (iv) socio-demographic model (consumption explained by household characteristics alone). 
The first result of the paper is that energy consumption is almost completely determined by technical properties of dwelling, the type of heating technology, and climate dummies. In the short run, without large investments in insulation and in new types of energy-efficient appliances, changes in energy consumption will be weak. The second contribution is to identify some of the main sources of energy conservation. It appears that in addition to standard measures such as roof insulation and the improvement of exposure in new buildings, the replacement of collective systems by individual heating systems will be efficient to improve buildings energy efficient. In contrast, the effect of double-glazing is surprisingly ambiguous, which raises the possibility of the existence of a "rebound effect" problem. The third contribution of this study is to propose an estimation of the price-elasticity and of the income-elasticity of energy consumption per $\mathrm{m}^{2}$, an issue which is not very well documented in the literature for French households. Results show that priceelasticities are in the range of what is generally found in other countries. Priceelasticity reaches -0.81 in flats and -0.46 in houses. This means that households are responsive to an increase in energy prices. In contrast, we find almost no variation of energy used per $\mathrm{m}^{2}$ with the level of household income. This result also is common in the literature.

Given these results, we can conclude that the challenge for environmental policies is to encourage households to undertake renovation in their dwelling. This is the role of some French environmental policies as a tax credit dedicated to sustainable development, a zero-rate bank loan or a subsidy. It will be interesting to study the effectiveness of these policies. 
Acknowledgement :

We thank INSEE and Centre Maurice Halbwachs for providing the data set (Enquête Logement 2006), Mareva Sabatier, Aude Pommeret and Dorothée Charlier for their advices and Grace Delobel for providing language help.

\section{References:}

Alberini, A., Gans, W., Velez-Lopez, D., 2011, Residential consumption of gas and electricity in the U.S.: The role of prices and income, Energy Economics.

ANAH, 2008, Modélisation des performances énergétiques du parc de logements. Etat énergétique du parc en 2008. Rapport détaillé, étude réalisée par J. Marchal sous la tutelle d'E. Lagandre.

Baker, P., Blundell, R., and Micklewright, J. 1989. Modelling household energy expenditures using micro-data, Economic Journal 99, no. 397: 720-738.

Baker, P., Blundell, R., 1991. The microeconometric approach to modeling energy demand: some results for UK households. Oxford Review of Economic Policy 7 (2), 54-76.

Bernard J.Th., Bolduc, D., Bélanger, D., 1996. Quebec residential electricity demand: a micro-econometric approach, Canadian Journal of Economics, XXIX (1), 92113.

Bernard J.Th., Bolduc, D., Yameogo N-D., 2011, A pseudo-panel data model of household electricity demand, Resource and Energy Economics 22

Branch, E.R., 1993. Short run income elasticity of demand for residential electricity using consumer expenditure survey data, The Energy Journal, 14 (4), 227-236.

Braun, F. G. 2010. Determinants of households' space heating type: A discrete choice analysis for German households. Energy Policy 38

Cayla, J.M. , Allibe, B. , Laurent, M.H. 2010, From practices to behaviors: estimating the impact of household behavior on space heating energy consumption. ACEEE Summer Study Proceedings on Energy Efficiency in Buildings 2010.

Cayla, J.M., Maizi, N., Marchand, C., 2011, The role of income in energy consumption behaviour: Evidence from French households data, Energy Policy

Charlier D., Risch, A. 2012. Evaluation of the impact of environmental public policy measures on energy consumption and greenhouse gas emissions in the French residential sector. Energy Policy 46.

Dubin, J.A., McFadden, D.L., 1984. An Econometric Analysis of Residential Electric Appliance Holdings and Consumption, Econometrica, 52(2), 345-362.

Garbacz, C., 1984a. Residential electricity demand: a suggested appliance stock equation. The Energy Journal, 5 (2), 150-154.

Garbacz, C., 1984b. A national micro-data based model of residential electricity demand: new evidence on seasonal variation, Southern Economic Journal 51. (1), 235-249.

Greening, L.A., Greene, D.L., Difiglio, C., 2000, Energy efficiency and consumption - the rebound effect - a survey, Energy Policy

Halvorsen, B., Larsen B., 2001, The Flexibility of Household Electricity Demand over Time. Resource and Energy Economics 23: 1-18.

Heckman, J., Robb, R., 1985, Alternative Methods for Evaluating the Impact of Interventions: An Overview, Journal of Econometrics 30(1-2), 239-267. 
Labandeira, X., Labeaga, J.M., Rodriguez M., 2006. A Residential Energy Demand System for Spain, The Energy Journal, 27(2), 87-111.

Larsen, B.M, Nesbakken, R., 2004. Household electricity end-use consumption: results from econometric and engineering models, Energy Economics, 26(2), 179200.

Leth-Petersen, S., Togeby, M., 2001, Demand for space heating in apartment blocks: measuring effects of policy measures aiming at reducing energy consumption, Energy Economics

Levinson, A., Niemann, S. 2004. Energy use by apartment tenants when landlords pay for utilities. Energy Economics 26.

Maruejols, L., and Yuong, D., 2011, Split incentives and energy efficiency in Canadian multi-family dwellings, Energy Policy

Meier, H., Rehdanz, K., (2010) Determinants of space heating expenditures in Great Breatain, Energy Economics

Murphy, K., Topel, R., 1985, Estimation and Inference in Two-step Econometric Models, Journal of Business and Economic Statistics 4, 370-379.

Nesbakken, R., 1999. Price Sensitivity of Residential Energy Consumption in Norway, Energy Economics, 21(6), 493-515.

Nesbakken, R., 2001. Energy Consumption for Space Heating: A DiscreteContinuous Approach, Scandinavian Journal of Economics, 103(1), 165-184.

Newell, R. G., Pizer, W. A., 2008. Carbon mitigation costs for the commercial building sector: Discrete-continuous choice analysis of multifuel energy demand, Resource and Energy Economics, 30(4), 527-539.

Parti, M., Parti C. 1980. The total and appliance-specific conditional demand for electricity in the household sector. Bell Journal of Economics, 309-21.

Rehdanz, K. 2007. Determinants of residential space heating expenditures in Germany. Energy Economics 29.

Santin, O. G., Itard, L., Visscher, H. 2009. The effect of occupancy and building characteristics on energy use for space and water heating in Dutch residential stock, Energy and Buildings

Sardianou E. 2008. Estimating space heating determinants: An analysis of Greek households, Energy and Buildings 40.

Song, D., Choi Y.J. 2012. Renewable and Sustainable Energy Reviews. Renewable and Sustainable Energy Reviews 16.

Swan, L.G., Ugursal, I., 2009. Modeling of end-use energy consumption in the residential sector: A review of modeling techniques, Renewable and Sustainable Energy Reviews 13 , pp. 1819-1835

Vaage, K., 2000. Heating technology and energy use: a discrete/continuous choice approach to Norwegian household energy demand, Energy Economics, 22(6), 649666.

Vringer, K., Blok, T.A.K., 2007. Household energy requirement and value patterns, Energy Policy 35: 553-566.

Zagamé, P., 2008. Modèles de l'énergie et nouvelles théories du progrès technique, communication au Conseil Français de l'Energie. 
APPENDIX:

Table A1. Data description

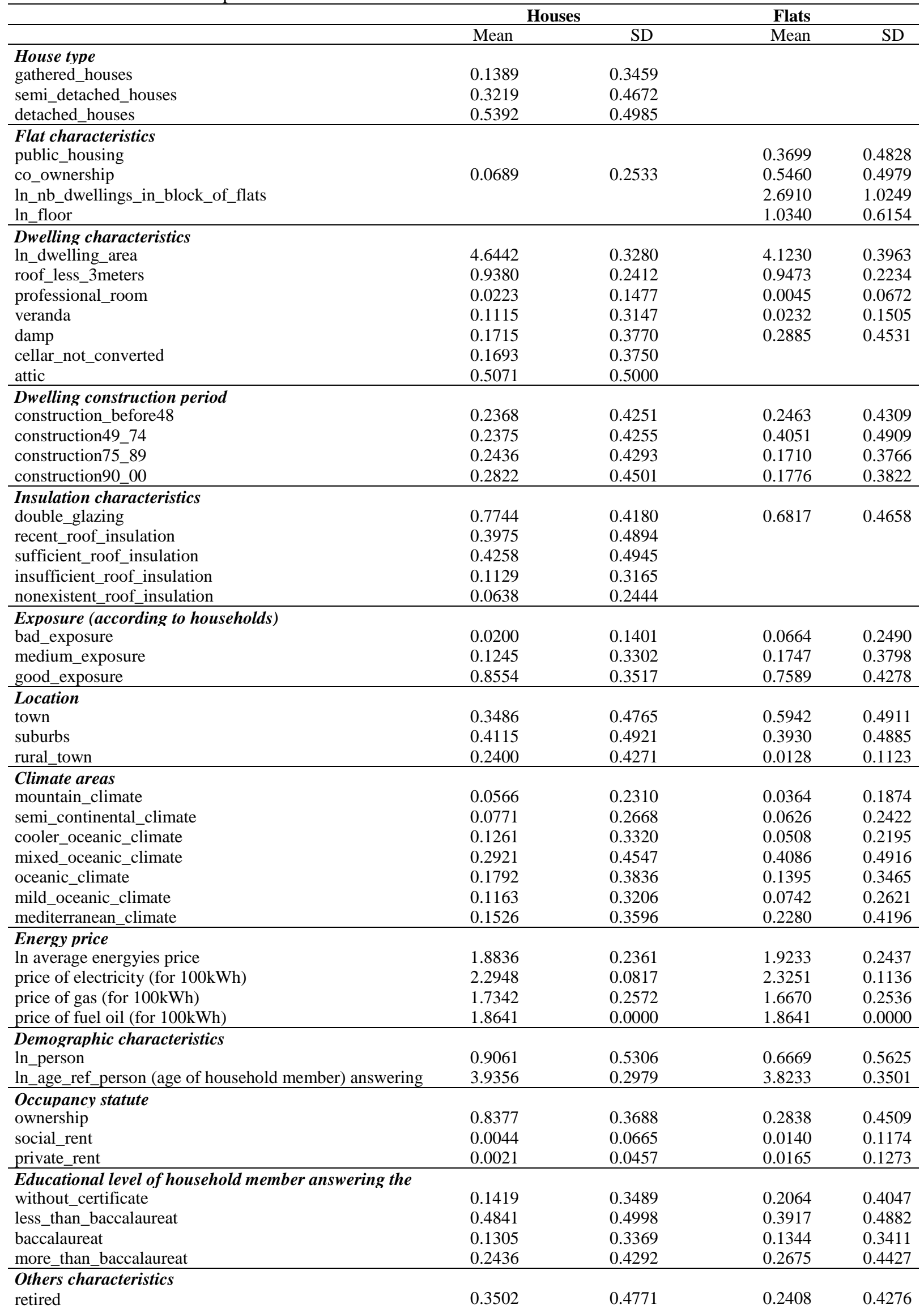




\begin{tabular}{llllr} 
unemployed & 0.0626 & 0.2422 & 0.1571 & 0.3639 \\
homemaker & 0.1379 & 0.3449 & 0.1387 & 0.3456 \\
\hline Standard living of households & & & & \\
ln_monthly_income_per_consumption_unit & 9.7379 & 0.6138 & 9.4397 & 0.7798 \\
ln_energy_consumption (by m ${ }^{2}$ ) & 5.1695 & 0.4577 & 5.0738 & 0.5066 \\
\hline nb observations & & 11476 & & 8373 \\
\hline
\end{tabular}

Map A.1. Climate Areas of France

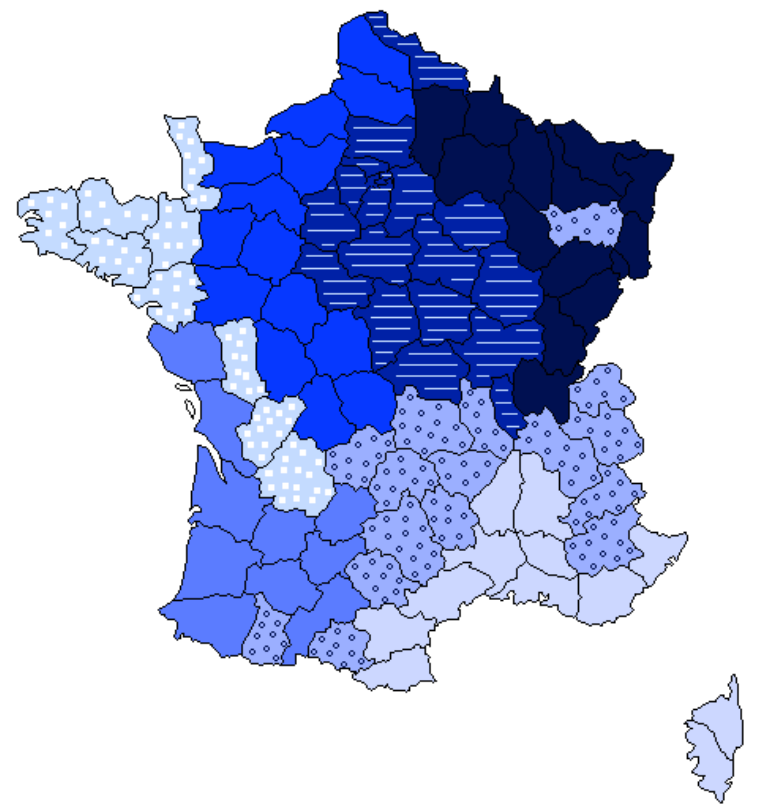

Mediterranean climate

Soft oceanic climate

Oceanic climate

Fresh oceanic climate

Oceanic climate range

Semi continental dimate

Mountain climate

Table A2. Multinomial probit regression: houses

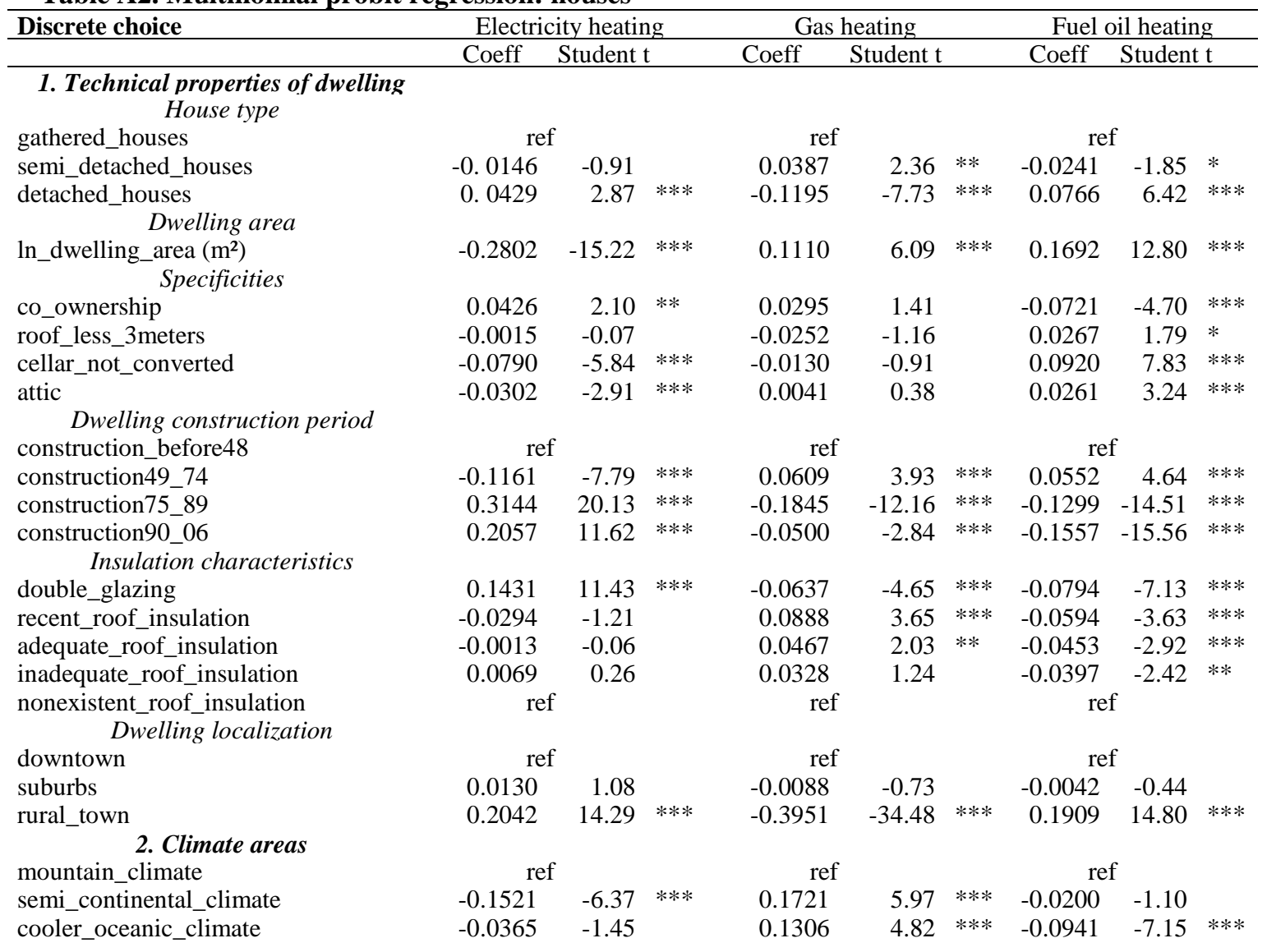




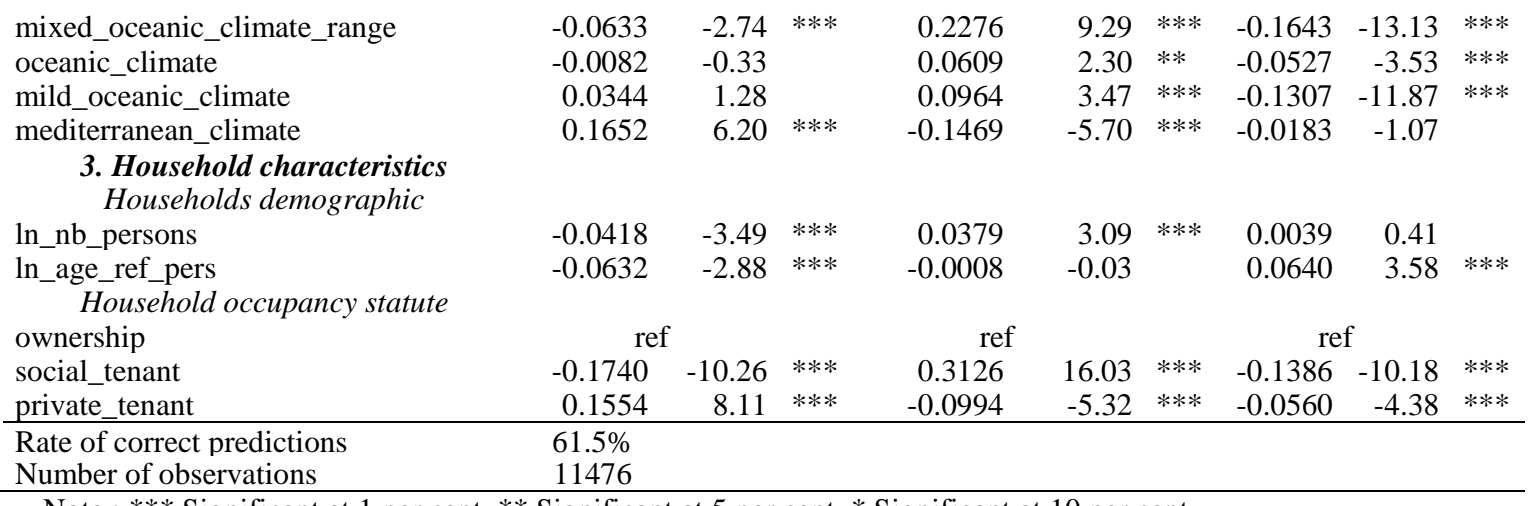

Note : *** Significant at 1 per cent. $* *$ Significant at 5 per cent. $*$ Significant at 10 per cent.

Table A3. probit multinomial. flats

\begin{tabular}{|c|c|c|c|c|c|c|c|c|c|}
\hline \multirow{3}{*}{ Discrete choice } & \multicolumn{6}{|c|}{ Individual heating } & \multirow{2}{*}{\multicolumn{3}{|c|}{$\begin{array}{l}\text { Collective heating } \\
\text { (gas or fuel oil) }\end{array}$}} \\
\hline & \multicolumn{3}{|c|}{ Electricity heating } & \multicolumn{3}{|c|}{ Gas heating } & & & \\
\hline & Coeff & Student & & Coeff & Student & & Coeff & Stude & \\
\hline \multicolumn{10}{|c|}{$\begin{array}{l}\text { 1.Technical properties of dwelling } \\
\text { Number of dwelling in apartment }\end{array}$} \\
\hline ln_nb_dwellings & -0.0342 & -4.30 & $* * *$ & -0.0049 & -0.67 & & 0.0390 & 11.33 & $* * *$ \\
\hline floor $(\ln )$ & -0.0166 & -1.39 & & -0.0136 & -1.26 & & 0.0302 & 6.26 & $* * *$ \\
\hline $\begin{array}{c}\begin{array}{c}\text { Dwelling arec } \\
\text { ln_dwelling_area }\left(\mathrm{m}^{2}\right) \\
\text { Specificities }\end{array}\end{array}$ & -0.4122 & -18.86 & $* * *$ & 0.3425 & 17.18 & $* * *$ & 0.0698 & 6.88 & $* * *$ \\
\hline public housing & -0.3781 & -25.73 & $* * *$ & 0.1499 & 7.11 & $* * *$ & 0.2282 & 10.71 & $* * *$ \\
\hline co_ownership & 0.0215 & 1.06 & & 0.0042 & 0.23 & & -0.0257 & -2.38 & $* *$ \\
\hline roof_less_3meters & 0.0067 & 0.22 & & 0.0046 & 0.17 & & -0.0113 & -0.63 & \\
\hline $\begin{array}{l}\text { Dwelling constructio } \\
\text { construction before } 48\end{array}$ & \multicolumn{3}{|c|}{ ref } & \multicolumn{2}{|c|}{ ref } & \multicolumn{4}{|c|}{ ref } \\
\hline construction49_74 & -0.2674 & -14.48 & $* * *$ & 0.0104 & 0.56 & & 0.2570 & 15.45 & $* * *$ \\
\hline construction75_89 & 0.0991 & 4.38 & $* * *$ & -0.1209 & -6.08 & $* * *$ & 0.0219 & 1.74 & * \\
\hline \multirow{2}{*}{\multicolumn{10}{|c|}{ Insulation characteristics }} \\
\hline & & & & & & & & & \\
\hline \multicolumn{10}{|c|}{ Dwelling localization } \\
\hline downtown & \multicolumn{2}{|c|}{ ref } & & \multicolumn{2}{|c|}{ ref } & \multicolumn{4}{|c|}{ ref } \\
\hline suburbs & -0.0051 & -0.33 & & 0.0003 & 0.02 & & 0.0048 & 0.73 & \\
\hline rural_town & 0.3732 & 11.59 & $* * *$ & -0.3296 & -13.01 & $* * *$ & -0.0435 & -2.44 & $* *$ \\
\hline \multicolumn{10}{|c|}{ 2. Climate areas } \\
\hline mountain climate & \multicolumn{2}{|c|}{ ref } & & \multicolumn{2}{|c|}{ ref } & \multicolumn{4}{|c|}{ ref } \\
\hline semi_continental_climate & -0.1659 & -3.44 & $* * *$ & 0.1228 & 2.89 & $* * *$ & 0.0431 & 1.79 & $*$ \\
\hline cooler_oceanic_climate & -0.0131 & -0.26 & & 0.0045 & 0.10 & & 0.0086 & 0.46 & \\
\hline mixed_oceanic_climate & 0.1134 & 2.81 & $* * *$ & -0.1183 & -3.34 & $* * *$ & 0.0048 & 0.33 & \\
\hline oceanic_climate & -0.0839 & -1.97 & $* *$ & 0.1197 & 3.03 & $* * *$ & -0.0358 & -3.21 & $* * *$ \\
\hline mild_oceanic_climate & 0.1022 & 2.38 & ** & -0.0418 & -1.03 & & -0.0603 & -7.52 & $* * *$ \\
\hline mediterranean_climate & 0.2286 & 6.07 & $* * *$ & -0.1476 & -4.27 & $* * *$ & -0.0809 & -8.27 & $* * *$ \\
\hline \multirow{2}{*}{\multicolumn{10}{|c|}{$\begin{array}{l}\text { 3. Household characteristics } \\
\text { Households demographic characteristics }\end{array}$}} \\
\hline & & & & & & & & & \\
\hline ln_nb_persons & 0.0256 & 1.86 & $*$ & -0.0233 & -1.85 & $*$ & -0.0023 & -0.43 & \\
\hline ln_age_ref_pers & 0.0055 & 0.25 & & -0.0200 & -0.99 & & 0.0145 & 1.61 & \\
\hline Household occupanc & & & & & & & & & \\
\hline ownership & re & & & ref & & & ref & & \\
\hline tenant & 0.1559 & 8.34 & $* * *$ & -0.0749 & -4.23 & $* * *$ & -0.0810 & -7.99 & $* * *$ \\
\hline $\begin{array}{l}\text { Rate of correct predictions } \\
\text { Number of observations }\end{array}$ & $\begin{array}{c}64.9 \% \\
8373\end{array}$ & & & & & & & & \\
\hline
\end{tabular}

Table A4. Tests of overidentifying restrictions:

\begin{tabular}{lll}
\hline & Houses estimation & Flats estimation \\
\hline Instruments & Gas city price in 1986 and 1996 & $\begin{array}{l}\text { Electricity price in 1986 and price of the } \\
\text { electricity subscription }\end{array}$ \\
& & P-value $=0.4900$ \\
Sargan test & P-value $=0.1903$ & P-value $=0.4910$ \\
Basmann test & P-value $=0.1912$ & \\
\hline
\end{tabular}


Table A5. Estimates of household energy consumption per $\mathbf{m}^{2}$ in a year: flats

Linear regression for flats. Continuous choice. Double least Squared.

Explained variable: Household energy consumption by $\mathrm{m}^{2}$ a year (in logarithm)

Explanatory factors

1.Technical properties of the housing unit

Collective dwelling characteristics

$\mathrm{nb}$ of dwellings in blocks of flats $(\ln )$

floor $(\ln )$

ln_dwelling_area $\left(\mathrm{m}^{2}\right)$

Dwelling area

roof less 3meters

Specificities

veranda

damp

construction_before 48

Dwelling construction period

construction49_74

construction75_89

construction90_05

double_glazing

double_glazing*construction49_74

double_glazing*construction75_89

double glazing*construction90_05

Dwelling exposure (according to households)

poor exposure

medium_exposure

good_exposure

mountain_climate

2. Climate areas

semi_continental_climate

cooler_oceanic_climate

mixed_oceanic_climate

oceanic climate

mild_oceanic_climate

mediterranean_climate

predicted probability to choose individual electric heating

predicted probability to choose individual gas heating

predicted probability to choose collective heating (gas or fuel oil)

\section{Energy price}

In_average energy_price

5. Household socio-demographic characteristics

Household demographic characteristics

ln_nb_persons

ln_age_ref_person (age of household member answering the questions in the survey)
Household occupancy statute

rent

rent*area

social flat (subsidised)

Coefficient

Student $\mathrm{t}$

$\begin{array}{rrr}-0.0252 & -3.92 & * * * \\ -0.0630 & -7.47 & * * * \\ & & \\ -0.4853 & -14.34 & * * * \\ & & \\ 0.0376 & 1.67 & * \\ 0.0131 & 0.39 & \\ 0.0412 & 4.06 & * * *\end{array}$

$0.0412 \quad 4.06 * * *$

ref

$-0.0440 \quad-1.49$

$-0.0472-1.85$

$-0.2012-3.12 * * *$

$-0.0548 \quad-2.67 \quad * * *$

$0.0409 \quad 1.70 *$

$0.0309 \quad 1.05$

$0.1194 \quad 1.80 *$

ref

$-0.0414-1.95 *$

$\begin{array}{lll}-0.0397 & -2.08 * *\end{array}$

ref

0.0696

$-0.0233$

0.0458

$-0.2095$

$-0.0494$

$-0.0482$

$2.31 * *$

$-0.73$

$1.78 *$

$-7.70 * * *$

$-1.67 *$

ref

0.1262

0.2165

$1.92 *$

$2.59 * *$

$-0.8152-19.81 * * *$

$0.1934 \quad 18.46 * * *$

$0.0830 \quad 3.83 * * *$

$0.4780 \quad 3.95 * * *$

$-0.1150 \quad-3.97 * * *$

$-0.0969 \quad-3.75 * * *$

Educational level of household member

without_certificate

brevet_diploma or vocational training qualification

baccalaureate

baccalaureat +2 years or more

Income and others characteristics

In annual income per consumption unit

ref

$-0.0267 \quad-2.03 * *$

$-0.0381 \quad-2.24 * *$

$-0.0137-0.88$

$0.0038 \quad 0.49$

$0.0058 \quad 0.37$

$0.0245 \quad 1.73 *$

unemployed

0.0380

$2.54 * *$

homemaker

8.3024

number of observations

0.3468

Note: $* * *$ Significant at 1 per cent. $* *$ Significant at 5 per cent. * Significant at 10 per cent. 